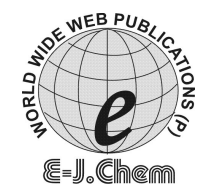

http://www.e-journals.net

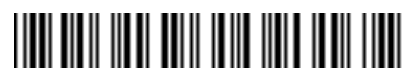

ISSN: 0973-4945; CODEN ECJHAO

E-Journal of Chemistry

Vol. 4, No. 4, pp. 487-495, October 2007

\title{
Synthesis of Nano-Crystalline $\mathrm{LiNd}_{\mathrm{x}} \mathrm{Mn}_{2-\mathrm{x}} \mathrm{O}_{4}$ Powder by Novel Cam-Microwave Assisted Sol-Gel Method
}

\author{
K. SURYAKALA and R.VENCKATESH*
}

Lithium ion battery Research Lab, Department of Industrial Chemistry, Alagappa University, Karaikudi-630 003, Tamilnadu, India

*Advanced Materials Research Laboratory, Department of Science \& Humanities, Kumaraguru College of Technology, Coimbatore - 641 006, Tamilnadu, India.

Received 7 February 2007; Accepted 4 March 2007

\begin{abstract}
With the advancement of nanotechnology, there is an interest in the replacement of conventional materials by nanomaterials. There is a reasonable chance that as the active mass of electrode for lithium batteries is comprised of smaller particles, they will perform better in terms of capacity, power, rate capability and stability. $\mathrm{LiMn}_{2} \mathrm{O}_{4}$ is inexpensive material but it shows rather poor cyclic performance. The electrochemical performance of spinel type $\mathrm{LiMn}_{2} \mathrm{O}_{4}$ has been effectively improved with doping of $\mathrm{Nd}$ the "bottom-up" approach of $\mathrm{LiMn}_{2} \mathrm{O}_{4}$ and $\mathrm{LiNd}_{\mathrm{x}} \mathrm{Mn}_{2-\mathrm{x}} \mathrm{O}_{4}(\mathrm{x}=0.1,0.2,0.3$ and 0.4$)$ synthesized by citric acid modified microwave assisted sol-gel method. $\mathrm{LiMn}_{2} \mathrm{O}_{4}$ has been synthesized from nitrates and acetates. Citric acid was added as a complexing agent and acryl amide acts as a gelling agent. This technique offers better homogeneity, preferred surface morphology, reduced heat-treatment conditions, sub-micron sized particles and better crystallinity. The structure and the electrochemical performances of the samples are characterized by Xray diffraction, scanning electron microscopy, transmission electron microscopy, cyclic voltammetry and charge-discharge testing. XRD data shows both samples exhibit the same pure spinel phase. Nano crystalline $\mathrm{LiNd}_{0.3} \mathrm{Mn}_{1.7} \mathrm{O}_{4}$ sample has a smaller morphology including small particle size and the homogeneous particle distribution compared to the other compositions.
\end{abstract}

Keywords : Lithium-ion battery; Doped lithium manganese spinels; Cyclic voltammetry;

\section{Introduction}

Lithium ion batteries are well regarded as new promising power sources for both portable electronic devices and zero emission vehicles (ZEV) due to their longer cycle life and higher energy density than other rechargeable battery systems. Currently $\mathrm{LiCoO}_{2}{ }^{1}, \mathrm{LiNiO}_{2}{ }^{2}$ and $\mathrm{LiMn}_{2} \mathrm{O}_{4}{ }^{3}$ are the main positive electrode materials for lithium-ion batteries. In comparison 
$\mathrm{LiNiO}_{2}$ and $\mathrm{LiCoO}_{2}$, spinel $\mathrm{LiMn}_{2} \mathrm{O}_{4}$ has some advantages such as lower cost, higher abundance of $\mathrm{Mn}$ in the earth, high safety and lower toxicity ${ }^{4}$. The electrochemical properties of the electrode materials are strongly depends on the physical and chemical properties like crystalline size, stoichiometry, homogeneity etc $^{5}$. However, the preparation of spinel $\mathrm{LiMn}_{2} \mathrm{O}_{4}$ involves at high temperature as high as $700-900^{\circ} \mathrm{C}$ solid-state reactions starting from the raw materials, such as manganese oxides, nitrate or carbonate with lithium hydroxide, nitrate or carbonate. The final products usually contains larger irregular particle, in a broader size distribution, as well as impurity phases. And also, this method could not provide good control on the crystalline growth, compositional homogeneity, morphology and microstructure ${ }^{6-9}$. Therefore, in order to overcome these disadvantages, various new techniques have been developed. Such techniques are based on the processes of co-precipitation, ion-exchange, or thermal decomposition at low temperatures of appropriate organic precursors obtained by sol-gel ${ }^{10}$, Pechini ${ }^{11}$, freezedrying $^{12}$, melt-impregnation ${ }^{13}$, or citric acid gel ${ }^{14}$ methods. These methods lead to homogeneous spinel materials with small particle size at the low cost of expensive reagents and process complexity.

In this work, an attempt has been to stabilize the $\mathrm{LiMn}_{2} \mathrm{O}_{4}$ spinel structure by a Citric Acid Modified (CAM) microwave assisted sol-gel method that employs citric acid as a chelating agent and acryl amide as a gelling agent with cobalt as dopant. This soft chemistry technique offers many advantages such as better homogeneity, low calcination temperature, shorter heating time, regular morphology, sub-micron sized particles, less impurities, large surface area, and good control of stoichiometry.

\section{Experimental}

\section{Synthesis procedure}

All the chemical reagents used in the experiments were analytical grade without further purification. $\mathrm{LiMn}_{2} \mathrm{O}_{4}$ and $\mathrm{LiNd}_{\mathrm{x}} \mathrm{Mn}_{2-\mathrm{x}} \mathrm{O}_{4}$ powders were synthesized by citric acid Modified microwave-assisted sol-gel method, which is schematically represented in Figure 1. A stoichiometric amount of lithium nitrate, manganese acetate and neodymium oxide were dissolved in triple distilled water. A calculated amount of citric acid was added as a complexing agent followed by the addition of acryl amide. Here, the acryl amide acts as a gelling agent. The resulting solution was mixed with continuous magnetic stirring at $90{ }^{\circ} \mathrm{C}$ until a clear viscous gel occurs. The obtained precursor was preserved under vacuum at $100{ }^{\circ} \mathrm{C}$ for $12 \mathrm{~h}$ to eliminate water adequently and then was placed in microwave oven. The microwave power operated at $100 \%$ $(650 \mathrm{~W})$ for $20 \mathrm{~min}$. After the microwave treatment, the samples were calcined at $550{ }^{\circ} \mathrm{C}$ for $6 \mathrm{~h}$, followed by cooling to room temperature slowly.

\section{Physical characterization}

The thermal decomposition behaviour of the $\mathrm{LiMn}_{2} \mathrm{O}_{4}$ and $\mathrm{LiNd}_{\mathrm{x}} \mathrm{Mn}_{2-\mathrm{x}} \mathrm{O}_{4}$ precursor samples was made using a simultaneous TG/DTA thermal analyzer (STA -1500) at the heating rate of $10^{\circ} \mathrm{C} / \mathrm{min}$ under ambient atmosphere. The purity and structural conformity of the powder was confirmed by JEOL X-ray diffraction analysis (JDX-8030) using $\mathrm{Cu} \mathrm{K} \alpha$ radiation. The diffraction patterns were obtained at $25^{\circ} \mathrm{C}$ in the range $10^{\circ} \geq 2 \theta \leq 70$. The step size and scan rate were set at 0.1 and $2{ }^{\circ} \mathrm{C} \mathrm{min}^{-1}$, respectively. The shape and size of the microstructure of the particles were observed using Scanning electron microscopy JEOL (JSM-840A) and Transmission electron microscope JEOL - (JEM -100SX). 


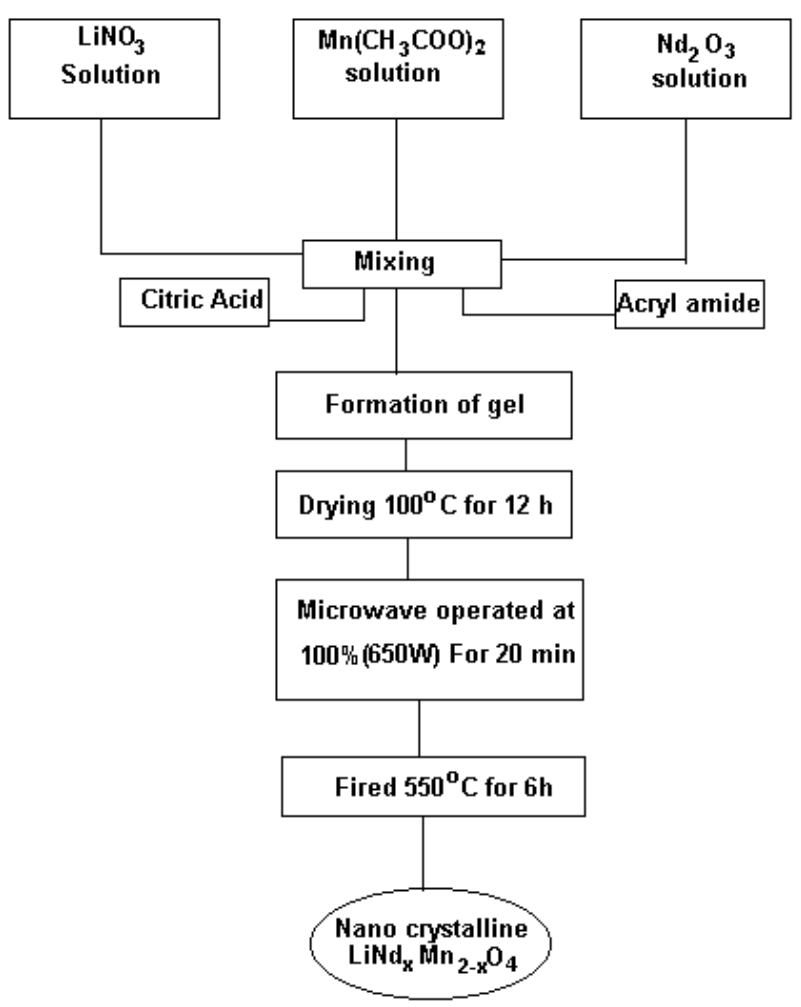

Figure 1. Flow chart for the preparation of cathode materials by CAM microwave assisted sol-gel method.

\section{Electrochemical characterization}

In order to assess the cycling behaviour of the synthesized cathode materials, cyclic voltammetry and charge / discharge studies were conducted by fabricating 2016 button-type electrochemical cells with the configuration of $\mathrm{C} / \mathrm{LiMn}_{2} \mathrm{O}_{4}$ and $\mathrm{LiNd}_{\mathrm{x}} \mathrm{Mn}_{2-\mathrm{x}} \mathrm{O}_{4}$ and employing $\mathrm{Li}^{+}$ion conducting, $\mathrm{LiClO}_{4}$ electrolyte. The cathode was prepared by mixing synthesized powders, acetylene black and a PVDF (polyvinylidene difluoride) binder dissolved with 2-NMP in a 80: 10:10 weight ratio. The above composite material was mixed and was placed in a die and pressed on to an expanded aluminium foil at a pressure of 5 tones $\mathrm{cm}^{-2}$ using a hydraulic press to yield circular pellet electrodes. The pellets were then dried at $110^{\circ} \mathrm{C}$ in an air oven. Cyclic voltammograms were recorded at a slow scan rate of $1 \mathrm{mV} / \mathrm{s}$ over the potential range $3-4.5 \mathrm{~V}$ using an EG\&G electrochemical analyzer. The synthesized cathode electrodes were examined for their capacity by constant current charge / discharge at potential window $3.0 \mathrm{~V}-4.5 \mathrm{~V}$ at a constant current density of $0.1 \mathrm{~mA} / \mathrm{cm}^{2}$ using WonATech Potentiostat/galvanostat instrument (WPG100 South Korea).

\section{Results and Discussion}

Thermal analysis

Figure 2 shows the phase formation of $\mathrm{LiMn}_{2} \mathrm{O}_{4}$ begins at around 305 and $312^{\circ} \mathrm{C}$ followed by the complete composition of precursor occurred at 425 and $450{ }^{\circ} \mathrm{C}$, respectively. 
The above discussion revealed that the phase formation and /or complete crystallization of $\mathrm{LiMn}_{2} \mathrm{O}_{4}$ precursor of citric acid-acryl amide combination occurs at lower temperature.

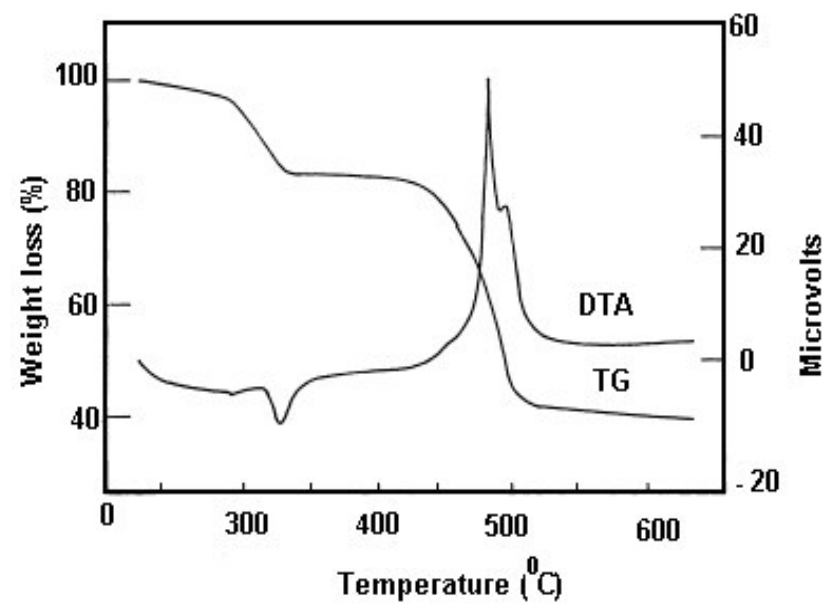

XRD studies

Figure 2. TG/TDA result on $\mathrm{LiNd}_{0.3} \mathrm{Mn}_{1.7} \mathrm{O}_{4}$

The XRD patterns of products are shown in Figure 3(a-e) The XRD patterns show that the spinel $\mathrm{LiMn}_{2} \mathrm{O}_{4}$ and $\mathrm{LiNd}_{\mathrm{x}} \mathrm{Mn}_{2-\mathrm{x}} \mathrm{O}_{4}$ powders have pure and crystalline in nature in all the compositions. Impurity phases such as $\mathrm{Li}_{2} \mathrm{CO}_{3}$ and $\mathrm{Mn}_{2} \mathrm{O}_{3}$ are often formed in other low temperature synthesis techniques ${ }^{15}$ are not observed. The main diffraction peaks of cubic spinel $\mathrm{LiMn}_{2} \mathrm{O}_{4}$ phase, such as (111), (311) and (400) is well developed. This means that lithium ions occupied tetrahedral 8a sites and manganese also occupied octahedral $16 \mathrm{~d}$ sites. From the statistics listed in Table 1 . It can be seen that $\mathrm{LiNd}_{\mathrm{x}} \mathrm{Mn}_{2-\mathrm{x}} \mathrm{O}_{4}$ has larger lattice parameter $\left(8.2327 \AA\right.$ ) value comparing with $\mathrm{LiMn}_{2} \mathrm{O}_{4}(8.2077 \AA)$.

Table 1. Lattice parameter of samples

\begin{tabular}{ccc}
\hline Sample & Lattice parameter $(\AA)$ & Unit cell volume $(\AA)$ \\
\hline $\mathrm{LiMn}_{2} \mathrm{O}_{4}$ & 8.2077 & 552.926 \\
$\mathrm{LiNd}_{0.1} \mathrm{Mn}_{1.9} \mathrm{O}_{4}$ & 8.2327 & 557.984 \\
$\mathrm{LiNd}_{0.2} \mathrm{Mn}_{1.8} \mathrm{O}_{4}$ & 8.2325 & 557.984 \\
$\mathrm{LiNd}_{0.3} \mathrm{Mn}_{1.7} \mathrm{O}_{4}$ & 8.2328 & 557.994 \\
$\mathrm{LiNd}_{0.4} \mathrm{Mn}_{1.6} \mathrm{O}_{4}$ & 8.2315 & 557.990 \\
\hline
\end{tabular}

SEM and TEM analysis

Particle morphology was examined by scanning electron microscopy, which shows that $\mathrm{LiMn}_{2} \mathrm{O}_{4}, \quad \mathrm{LiNd}_{0.1} \mathrm{Mn}_{1.9} \mathrm{O}_{4}, \quad \mathrm{LiNd}_{0.2} \mathrm{Mn}_{1.8} \mathrm{O}_{4}, \quad \mathrm{LiNd}_{0.3} \mathrm{Mn}_{1.7} \mathrm{O}_{4}$ and $\mathrm{LiNd}_{0.4} \mathrm{Mn}_{1.6} \mathrm{O}_{4}$ exhibit homogeneous particle distribution and relatively small particles (micron particle) with similar particle shape. The SEM photographs for undoped and doped $\mathrm{LiNd}_{0.3} \mathrm{Mn}_{1.7} \mathrm{O}_{4}$ were presented in Figure $4(\mathrm{a}, \mathrm{b})$. The well dispersed particles are the result of the treatment of microwave as reported elsewhere ${ }^{16}$, because the microwave heated from inside of the precursor and thus provided a uniform heating environment which shortened the synthesizing time and overcome the agglomeration of particles ${ }^{17}$. Such kind of morphology is very important for both the high specific capacity and good cycleability of the materials ${ }^{18-20}$. 
The SEM studies reveal $\mathrm{LiNd}_{0.3} \mathrm{Mn}_{1.7} \mathrm{O}_{4}$ material to be of finer size and with less aggregation. It should be most suited cathode material amongst all other compositions.

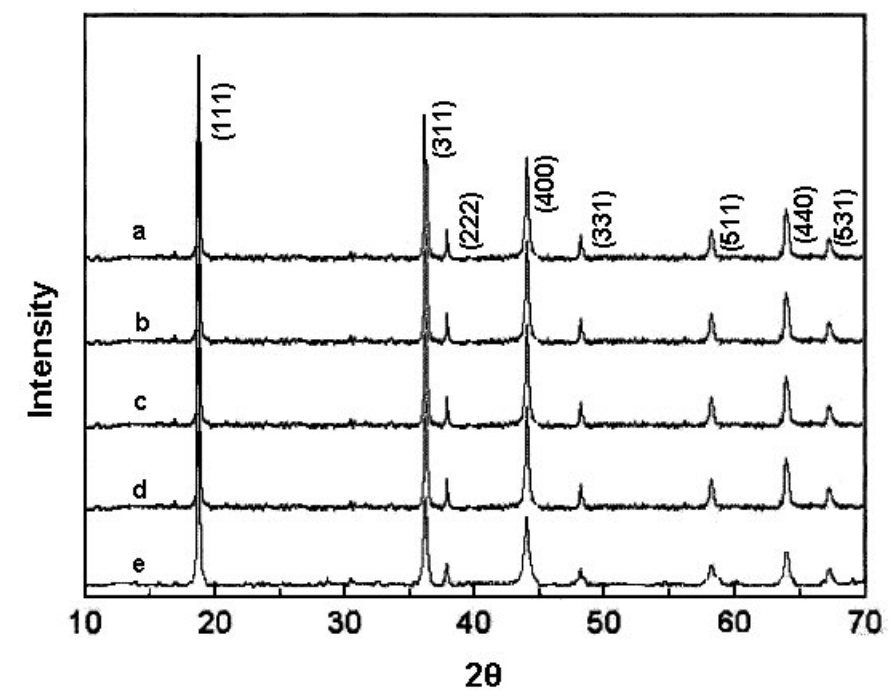

Figure 3. XRD patterns of (a) $\mathrm{LiMn}_{2} \mathrm{O}_{4}$ (b) $\mathrm{LiNd}_{0.1} \mathrm{Mn}_{1.9} \mathrm{O}_{4}$ (c) $\mathrm{LiNd}_{0.2} \mathrm{Mn}_{1.8} \mathrm{O}_{4}$ (d) $\mathrm{LiNd}_{0.3} \mathrm{Mn}_{1.7} \mathrm{O}_{4}$ and (e) $\mathrm{LiNd}_{0.4} \mathrm{Mn}_{1.6} \mathrm{O}_{4}$
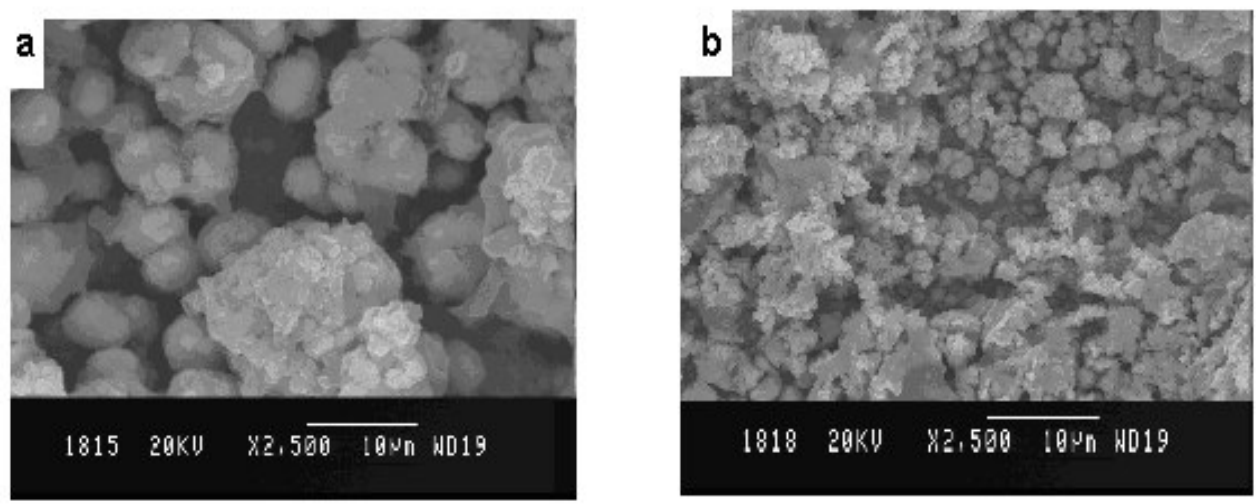

Figure 4. $\mathrm{SEM}$ images of (a) $\mathrm{LiMn}_{2} \mathrm{O}_{4}$ (b) $\mathrm{LiNd}_{0.3} \mathrm{Mn}_{1.7} \mathrm{O}_{4}$

Hence, TEM study was carried out only for this particular composition to get more clarity on the particle size. The TEM photographs for undoped and $\mathrm{LiNd}_{0.3} \mathrm{Mn}_{1.7} \mathrm{O}_{4}$ synthesized at $550^{\circ} \mathrm{C}$ are presented in Figure $5(\mathrm{a}, \mathrm{b})$. In the case of undoped $\mathrm{LiMn}_{2} \mathrm{O}_{4}$ the cluster formation is $\approx 60 \mathrm{~nm}$ and also the particle size is little larger when compared with the $\mathrm{Nd}$ doped material $\approx 40 \mathrm{~nm}$. The interlayer distance may be higher than that of the doped one due to the larger size of particles. The surface area of the electrode material is an important characteristic parameter that determines the energy and power density of a particular battery system. In the present study the surface area is expected to be higher for Nd doped cathode material because of lesser particle size. 


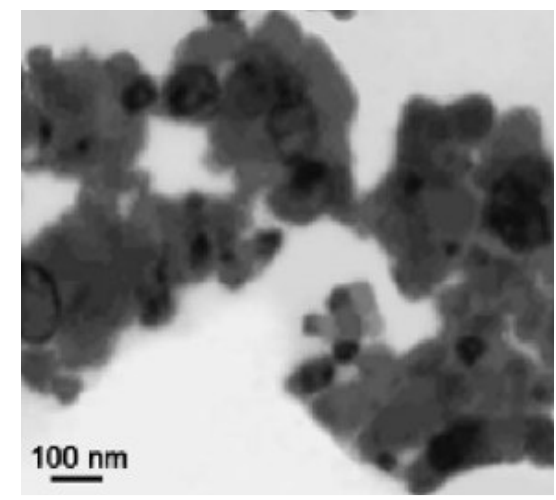

(a)

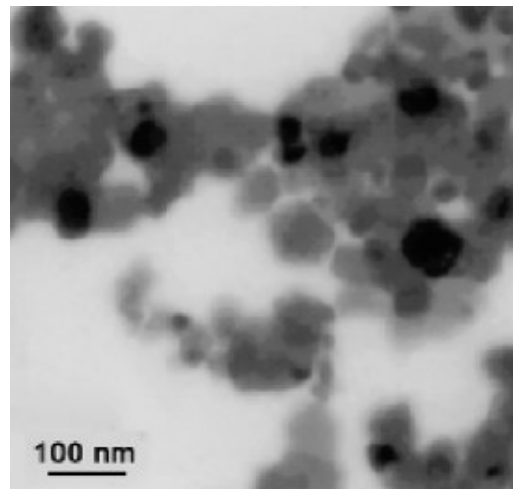

(b)

Figure 5. TEM photograph of (a) $\mathrm{LiMn}_{2} \mathrm{O}_{4}$ (b) $\mathrm{LiNd}_{0.3} \mathrm{Mn}_{1.7} \mathrm{O}_{4}$

\section{Cyclic voltammetry studies}

The electrochemical properties $\mathrm{Nd}$ synthesized $\mathrm{LiNd}_{\mathrm{x}} \mathrm{Mn}_{2-\mathrm{x}} \mathrm{O}_{4}(\mathrm{x}=0.0,0.1,0.2,0.3$ and 0.4$)$ were studied through cyclic voltammetric technique. The cathode active materials (80\%) were mixed with 10\%: 5\% weight percentage of acetylene black and polyvinylidene difluoride (PVDF) with NMethyl-2-pyrrolidione (NMP) binder solution. The prepared paste was casts on pure Al foil and cured at $110^{\circ} \mathrm{C}$ in a vacuum condition for $24 \mathrm{~h}$. A standard 2016 type coin cell was made using graphite as anode and synthesized material as cathode with polypropylene separator. The electrolyte used $1 \mathrm{M} \mathrm{LiClO}_{4} \mathrm{EC}$ (ethylene carbonate) $(1: 1 \mathrm{v} / \mathrm{v})$. All the setup was done in the argon filled glove box. The cyclic voltammetric properties of the cells were examined between the potential window of 3.0 and $4.5 \mathrm{~V}$ and the resulting voltammograms are presented in Figure 6(a-e).

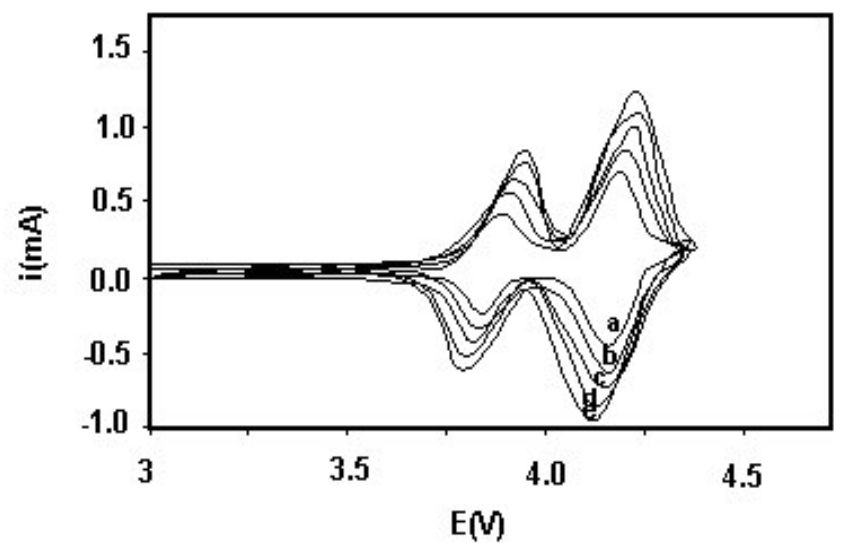

Figure 6. Cyclic voltammetry curve of (a) $\mathrm{LiMn}_{2} \mathrm{O}_{4}$ (b) $\mathrm{LiNd}_{0.1} \mathrm{Mn}_{1.9} \mathrm{O}_{4}$ (c) $\mathrm{LiNd}_{0.2} \mathrm{Mn}_{1.8} \mathrm{O}_{4}$ (d) $\mathrm{LiNd}_{0.3} \mathrm{Mn}_{1.7} \mathrm{O}_{4}$ and (e) $\mathrm{LiNd}_{0.4} \mathrm{Mn}_{1.6} \mathrm{O}_{4}$

The intercalation and deintercalation of lithium conveniently takes place in the potential range of interest in all the synthesized materials. Interestingly, the sample prepared $\mathrm{x}=0.3$ shows a well-decreased $\Delta \mathrm{Ep}$ and thus supports the inseration deinsertion process to be easier. 


\section{Charge-discharge studies}

The charge -discharge studies were performed at a constant current density of $0.1 \mathrm{~mA} / \mathrm{cm}^{2}$ in the potential range $3.0-4.5 \mathrm{~V}$. The recorded voltage capacity curves are shown in Figure 7(a-e) and Figure 8 . The first discharge curves show the capacity retention is higher for lower addition while at higher addition the capacity retention is much reduced. In the $50^{\text {th }}$ cycle, the capacity retention is $93.5 \%$ for $\mathrm{x}=0.1 ; 95.5 \%$ for $\mathrm{x}=0.2 ; 96.7 \%$ for $\mathrm{x}=0.3 ; 92.5 \%$ for $\mathrm{x}=0.4$ for all the doped cathode materials. However, for undoped material capacity retention is only $90.5 \%$. Alternatively the capacity fading rate of doped and undoped $\mathrm{LiMn}_{2} \mathrm{O}_{4}$ materials depicted in Figure 9 as bar chart where one could see $\mathrm{LiNd}_{0.3} \mathrm{Mn}_{1.7} \mathrm{O}_{4}$ cathode material for lithium battery application with capacity fading rate too low when compared to other compositions. The above discussion revealed that the nano-crystalline $\mathrm{LiNd}_{0.3} \mathrm{Mn}_{1.7} \mathrm{O}_{4}$ has very good reversibility when compared to other compositions. Because the smaller particle size of $\mathrm{LiNd}_{0.3} \mathrm{Mn}_{1.7} \mathrm{O}_{4}$ facilitates rapid diffusion of $\mathrm{Li}^{+}$ions which leads to good battery performance.

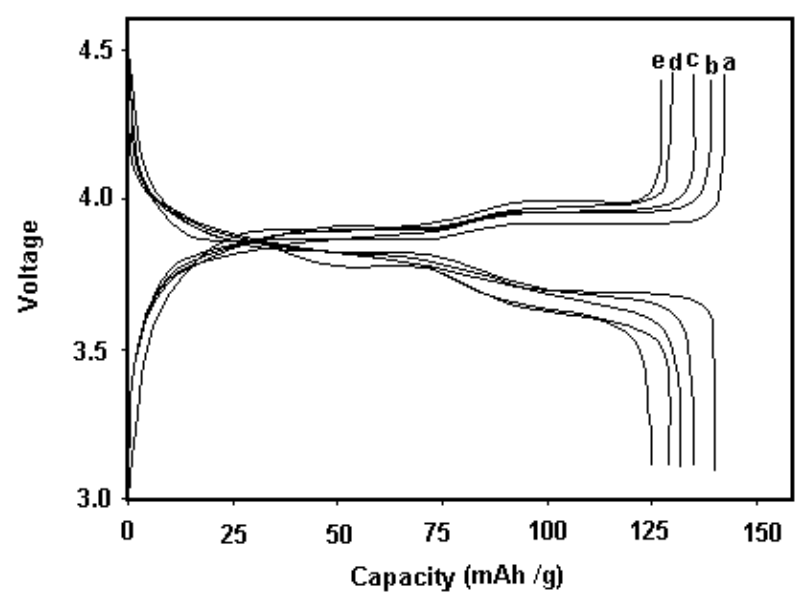

Figure 7. Charge/discharge curve of (a) $\mathrm{LiMn}_{2} \mathrm{O}_{4}$ (b) $\mathrm{LiNd}_{0.1} \mathrm{Mn}_{1.9} \mathrm{O}_{4}$ (c) $\mathrm{LiNd}_{0.2} \mathrm{Mn}_{1.8} \mathrm{O}_{4}$ (d) $\mathrm{LiNd}_{0.3} \mathrm{Mn}_{1.7} \mathrm{O}_{4}$ and (e) $\mathrm{LiNd}_{0.4} \mathrm{Mn}_{1.6} \mathrm{O}_{4}$

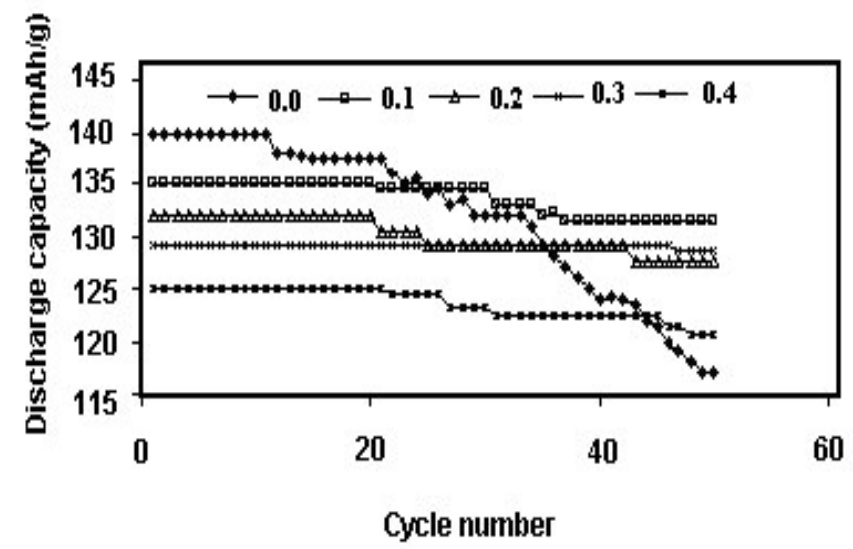

Figure 8. Plots of specific capacity vs. cycle no. of $\mathrm{LiMn}_{2} \mathrm{O}_{4}$ and $\mathrm{LiNd}_{\mathrm{x}} \mathrm{Mn}_{2-\mathrm{x}} \mathrm{O}_{4}(\mathrm{x}=0.1$, $0.2,0.3$ and 0.4 ) 


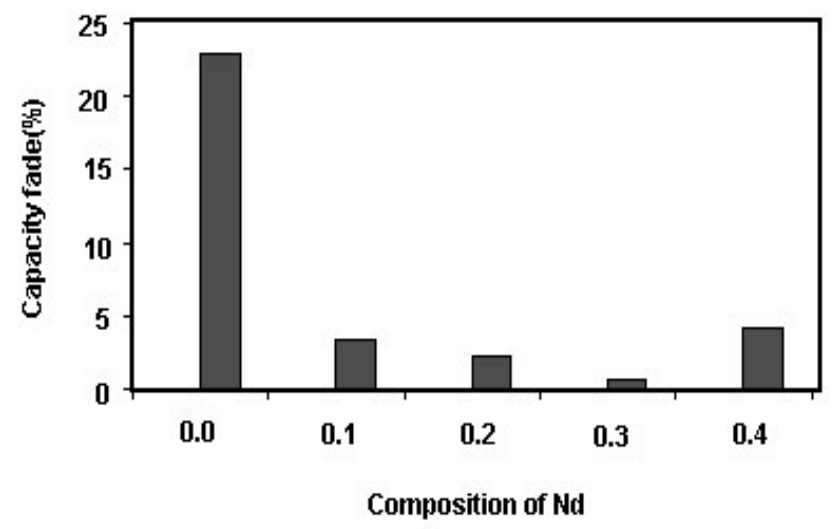

Figure 9. Capacity fading rate vs. in $\mathrm{LiMn}_{2} \mathrm{O}_{4}$ and $\mathrm{LiNd}_{\mathrm{x}} \mathrm{Mn}_{2-\mathrm{x}} \mathrm{O}_{4}$

$$
(\mathrm{x}=0.1,0.2,0.3 \text { and } 0.4)
$$

\section{Conclusions}

Nano-crystalline phase pure $\mathrm{LiMn}_{2} \mathrm{O}_{4}$ and $\mathrm{LiNd}_{\mathrm{x}} \mathrm{Mn}_{2-\mathrm{x}} \mathrm{O}_{4}$ powders have been synthesized in bulk quantities by CAM microwave assisted sol-gel method. In this study, the rare earth element $\mathrm{Nd}^{3+}$ was used as dopant in the $\mathrm{LiMn}_{2} \mathrm{O}_{4}$ and the structure and the electrochemical properties were examined. XRD data showed that the $\mathrm{Nd}^{3+}$ doped sample has the similar phase with undoped sample, but has larger lattice parameter than that of the undoped $\mathrm{LiMn}_{2} \mathrm{O}_{4}$. Thermal studies and TEM studies show that $\mathrm{LiNd}_{0.3} \mathrm{Mn}_{1.7} \mathrm{O}_{4}$ at lower temperature with smaller nanoparticles than other compositions. An electrochemical investigation also shows that the product obtained by $\mathrm{LiNd}_{0.3} \mathrm{Mn}_{1.7} \mathrm{O}_{4}$ yield better capacity retention than the materials prepared by using other compositions.

Hence, $\mathrm{LiNd}_{0.3} \mathrm{Mn}_{1.7} \mathrm{O}_{4}$ is the effective composition in CAM microwave assisted solgel method for the synthesis of cubic spinel powder and the compound obtained by using this composition is an effective cathode material for lithium ion battery applications.

\section{References}

1. Chen Z and Dhan J R, Electrochim. Acta, 2004, 49, 1079.

2. Maruta J and Yamachi H, J.Power Sources, 2000, 90, 89.

3. He X, Li J, Yancaj, Jiang C and Wan C, Mater.Chem Phys. 2006, 95, 105.

4. Wu M, Zhang Q, Lu H and Chen A, Solid State Ionics, 2004, 169, 47-50.

5. Lee Y S, Sun Y K and Nahm K S, Solid State Ionics, 1998, 109, 185.

6. Gan Y and Dahn J R, J.Electrochem.Soc. 1996, 143, 100.

7. Endres P, Fuchs B, Sack S K, Brandt K, Becker G F and Praas H W, Solid State Ionics, 1996, 89, 221.

8. Momchilov A, Manev V, Nassalevska A and Kozawa A, J.Power Sources, 1993,41, 305.

9. Guan J and Liu M L, Solid State Ionics, 1998, 110, 21.

10. Liu W, Kowal K and Farrington G C, J.Electrochem.Soc, 1996, 143, 3590

11. Liu W, Farrington G C, Chaput F and Dunn B, J.Electrochem.Soc, 1996, 143, 879.

12. Zhecheva E N, Gorova M Yand Stoyanova R K, J.Mater. Chem, 1999, 9, 1559.

13. Xia Y Y, Takeshige H, Noguchi H and Yoshio M, J.Power Sources, 1995, 56, 61.

14. Hwang B J, Santhanam R, Liu D G and Tsai Y W, J.Power Sources, 2001, 102, 326. 
15. Hwang B J, Santhanam R and Liu D G, J.Power Sources, 2001, 101, 86.

16. Yang S T, Zhang Y F and Lv Q Z, J.Inorg.Mater, 2000, 15, 312.

17. Yan H, Huang X and Chen L, J.Power Sources, 1999, 81, 648.

18. Shokoohi F K, Tarascon J M, Wilkers B J, Guyomard D and Chang C C, J. Electrochem. Soc. 1992, 139, 1847.

19. Jang S W, Lee H Y, Shin K C and Lee S M, J.Power Sources, 2000, 88, 274.

20. Myung S T, Chung H T, Komaba S and Kumagai N, J.Power Sources, 2000, 90, 104. 


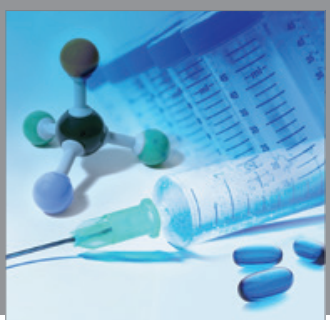

International Journal of

Medicinal Chemistry

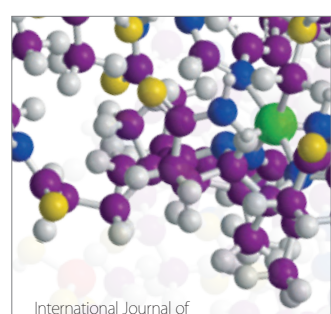

Carbohydrate Chemistry

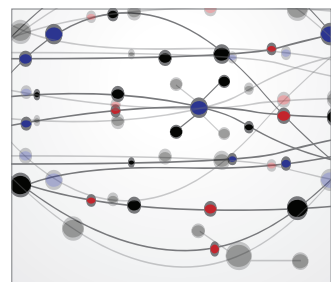

The Scientific World Journal
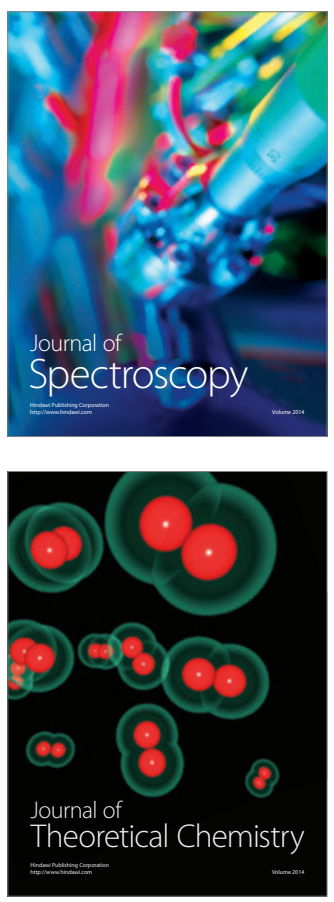
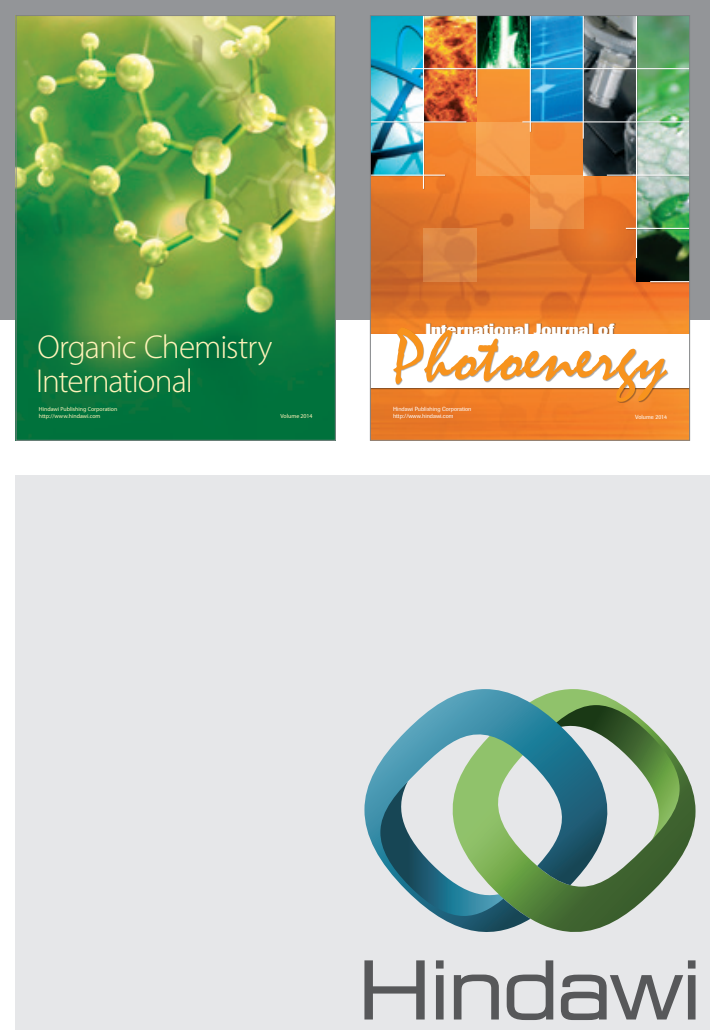

Submit your manuscripts at

http://www.hindawi.com
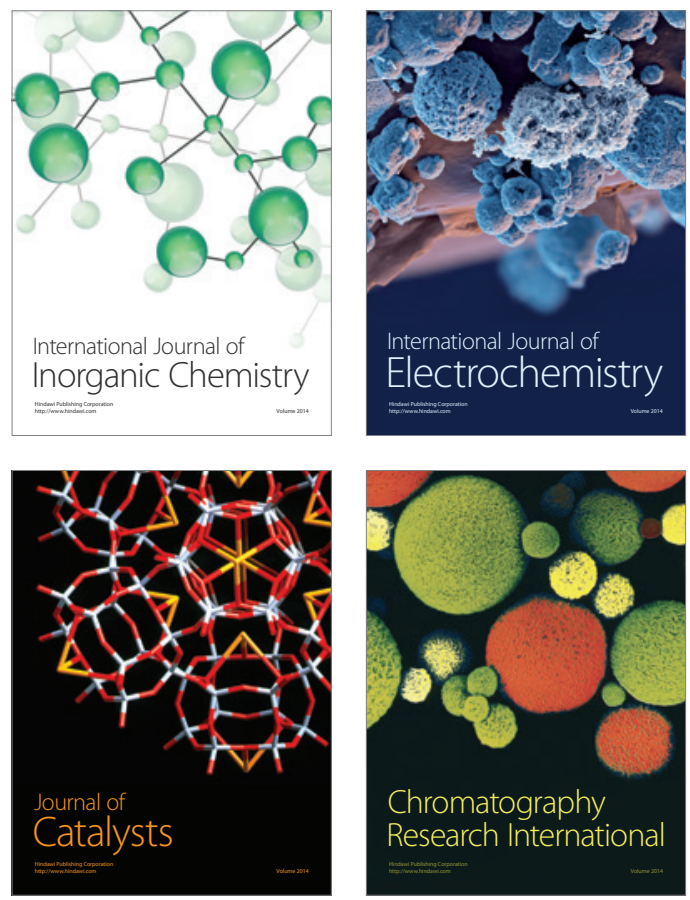
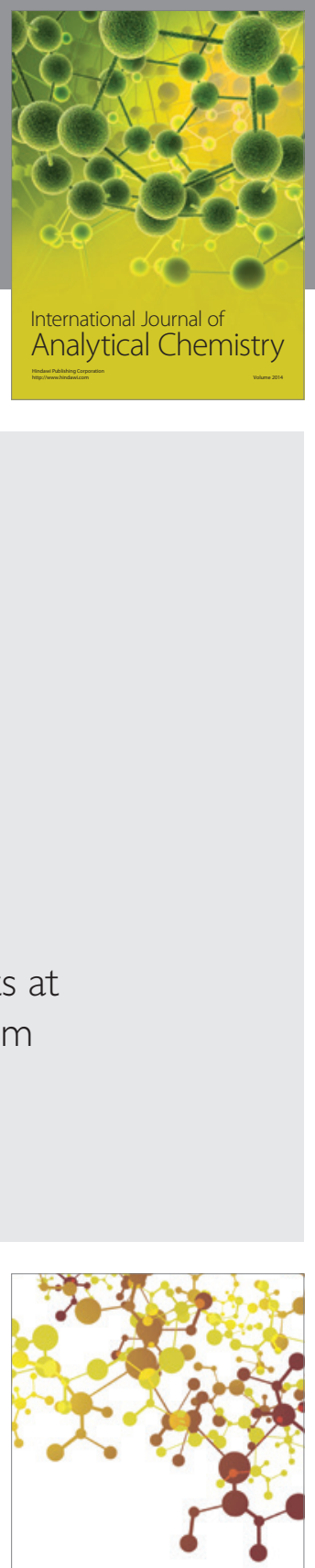

Journal of

Applied Chemistry
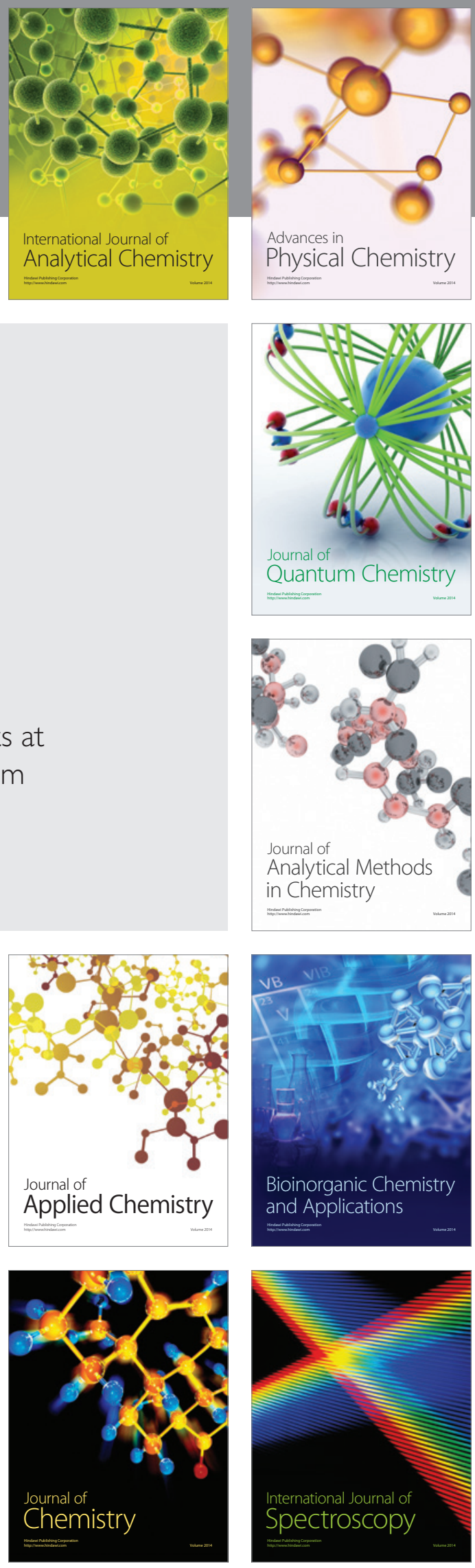